\title{
Identification of the Bacterial Leaf Spot Pathogen of Lettuce, Xanthomonas campestris pv. vitians, in Ohio, and Assessment of Cultivar Resistance and Seed Treatment
}

\author{
F. Sahin and S. A. Miller, Department of Plant Pathology, The Ohio State University, Ohio Agricultural Research \\ and Development Center, Wooster 44691
}

\begin{abstract}
Sahin, F., and Miller, S. A. 1997. Identification of the bacterial leaf spot pathogen of lettuce, Xanthomonas campestris pv. vitians, in Ohio, and assessment of cultivar resistance and seed treatment. Plant Dis. 81:1443-1446.

In 1995, a bacterial leaf spot disease was observed on lettuce plants grown on muck soils in north central Ohio. Characteristic symptoms were water-soaked circular, dark brown- or olivecolored spots, approximately 1 to $2 \mathrm{~mm}$ in diameter, along the margin of leaves; V-shaped lesions beginning at the leaf margins and advancing along the veins; and individual black spots scattered on the leaf surface. Five bacterial strains were isolated from infected leaves of two lettuce cultivars, Darkland and Go Go Green. These strains were identified as Xanthomonas campestris pv. vitians based on morphological, physiological, biochemical, and pathogenicity tests, as well as fatty acid methyl ester (FAME) analyses. One of the five strains tested was resistant to streptomycin sulfate $(100 \mu \mathrm{g} / \mathrm{ml})$, and none were resistant to copper sulfate. Eight commercial lettuce cultivars were evaluated for resistance to $X$. campestris pv. vitians. Of these cultivars, Redine was highly resistant; Focus and Crisp and Green were partially resistant; Slobolt, Tiara, and Carmona were susceptible; and Darkland and Go Go Green were highly susceptible to the pathogen. Surface disinfection with $0.52 \%$ sodium hypochlorite for 5 min nearly eliminated the bacterium from lettuce seed without affecting seed viability.
\end{abstract}

Leaf lettuce (Lactuca sativa L.) is a high-value vegetable crop grown on organic (muck) soils in Ohio. With approximately 580 acres planted annually and an estimated crop value of $\$ 2.5$ million (1), Ohio ranks third after California and Arizona in leaf lettuce production. Quality considerations are critical in the marketing of leaf lettuce, and the presence of leaf spots or other blemishes generally destroys marketability of the crop.

In 1995, a bacterial leaf spot disease was observed in numerous plantings of lettuce on muck soils in north central Ohio. Different lettuce cultivars were observed with symptoms suggestive of the bacterial leaf spot disease caused by Xanthomonas campestris pv. vitians: dark brown to black, water-soaked lesions along the margins of lower leaves, expanding towards leaf veins, and resulting in V-shaped lesions. Small individual black spots scattered on the leaf surface were also observed.

Corresponding author: S. A. Miller

E-mail: miller.769@osu.edu

This research was supported by Ataturk University, Erzurum, Turkey, and state and federal funds appropriated to the Ohio Agricultural Research and Development Center (OARDC), Ohio State University.

OARDC Research Article Number 144-97.

Accepted for publication 25 August 1997.

Publication no. D-1997-0930-04R

(C) 1997 The American Phytopathological Society
Bacterial leaf spot of lettuce was first reported in the United States in 1918 (3). Since then, the disease has been reported in many states, including California, Florida, and New York. This disease also has been reported in Japan, New Zealand, South Africa, and Italy $(2,4,8-10,14,17,19)$. However, it has not been previously reported in Ohio. The pathogen is known to survive on or in diseased plant debris for short periods of time. It is also known to be seedborne and can survive on dried seeds for extended periods (14). Contaminated seeds are considered the major source of primary inoculum, as well as the major means of long-distance spread of the pathogen. However, seed treatment strategies have not been reported. So far, resistance in $X$. campestris pv. vitians to copper and streptomycin, which are used to control bacterial diseases on foliage, has not been observed (10). Although differences in disease severity between the lettuce types cos (romaine), butterhead, and crisphead have been observed (10), no information has been published on resistance of individual lettuce cultivars to this disease. Such options should be evaluated in order to develop effective strategies for management of this disease in Ohio and elsewhere.

The objectives of this study were to (i) identify and characterize bacteria from lettuce plants exhibiting leaf spot symptoms, including sensitivity to copper and streptomycin; (ii) evaluate commercial lettuce cultivars typically grown in Ohio for resistance to $X$. campestris pv. vitians; and (iii) evaluate surface disinfection as a means of eliminating the bacteria from seed.

\section{MATERIALS AND METHODS}

Isolation of bacterial strains. In spring and summer 1995, lettuce plants exhibiting bacterial leaf spot symptoms were collected from commercial fields on muck soil in north central Ohio. Bacteria were isolated from diseased leaf tissues by cutting leaves into small pieces and soaking them in $2 \mathrm{ml}$ sterile, distilled water. The resulting suspension was streaked onto CKTM medium (15), which is semi-selective for Xanthomonas spp. The plates were incubated at $28^{\circ} \mathrm{C}$ for 5 days. Single bacterial colonies displaying characteristics of Xanthomonas spp. were selected and purified by re-streaking on yeast dextrose carbonate (YDC) agar (7). Five strains were selected for further tests. A type strain of $X$. campestris pv. vitians, LMG 938 (Laboratorium voor Microbiologie, Universiteit Gent, B-9000, Ghent, Belgium), was used as a positive reference culture for all determinative tests.

Strain identification and characterization. Bacterial strains were identified according to morphological, physiological, and biochemical tests described previously (4-5,13,16,18). Fatty acid methyl ester (FAME) profiles $(12,20)$ were determined for each strain using the Trypticase Soy Broth Agar (TSBA) database in the Microbial Identification System (MIS) Software package (MIS version no. 3.8, September 1994 update; MIDI Inc., Newark, Delaware). FAME profiles for each strain were compared with positive reference strains in the MIS library.

Pathogenicity tests were performed by using bacterial cultures grown on YDC for $48 \mathrm{~h}$ at $28^{\circ} \mathrm{C}$. Each strain was suspended in sterile distilled water and the bacterial concentration was adjusted to $10^{8} \mathrm{CFU} / \mathrm{ml}$. Leaves of 5-week-old lettuce plants (cv. Darkland) were dipped into the bacterial suspension. The inoculated plants were incubated in a mist chamber $(>90 \%$ relative humidity) for 3 days, then transferred to a greenhouse at 25 to $28^{\circ} \mathrm{C}$ for 5 days. Plants were observed for characteristic bacterial leaf spot symptoms on inoculated leaves. The plants were kept in a greenhouse for seed production, and disease development was observed at different growth stages.

$X$. campestris pv. vitians strains were tested for sensitivity to copper and streptomycin using a previously de- 
scribed procedure with some modifications (11).

Briefly, each strain was streaked on sucrose peptone agar (SPA) medium amended with copper sulfate (30 or 100 $\mu \mathrm{g} / \mathrm{ml})$ or streptomycin sulfate $(20,100$, or $150 \mu \mathrm{g} / \mathrm{ml})$. The plates were incubated for 4 to 6 days at room temperature. The presence of bacterial growth on SPA medium $20 \mu \mathrm{g} / \mathrm{ml}$ streptomycin sulfate indicated resistance.

Evaluation of commercial lettuce cultivars for resistance to $X$. campestris pv. vitians. Experiments were conducted from autumn 1995 to spring 1996 in a greenhouse at 25 to $28^{\circ} \mathrm{C}$. Eight commercial lettuce cultivars, Darkland, Go Go Green, Tiara, Slobolt, Carmona, Focus, Crisp and Green, and Redine, were evaluated for resistance to $X$. campestris pv. vitians based on disease severity, bacterial population in fresh leaf tissue, and percentage of seeds contaminated with $X$. campestris pv. vitians.

Plants were arranged in a completely randomized design with five replications of amended with $30 \mu \mathrm{g} / \mathrm{ml}$ copper sulfate or

a single plant per experiment. Five 6-weekold plants were inoculated by dipping them in a mixture of five virulent $X$. campestris pv. vitians strains at a total concentration of approximately $10^{8} \mathrm{CFU} / \mathrm{ml}$. The inoculated plants were incubated in a greenhouse for 8 to 10 days at 25 to $28^{\circ} \mathrm{C}$. Plants were observed for bacterial leaf spot symptoms 15 days after inoculation. Disease severity was rated using a 1 to 5 scale, in which $1=$ no disease, 2 = a few water-soaked lesions, $3=$ many spots with coalescence and slight plant wilting, 4 = severe wilting and defoliation, and 5 = plants dead.

$X$. campestris pv. vitians populations in leaf tissue were estimated by dilution plating. The two oldest, inoculated leaves, and two newer, noninoculated leaves from five plants of each cultivar were collected 15 and 25 days after inoculation, respectively, and chopped into small pieces. Five $\mathrm{g}$ fresh leaf tissue from each cultivar was macerated in a plastic bag (Agdia Inc, Elkhorn, IN) containing $1 \mathrm{ml}$ sterile distilled water/g leaf tissue (fresh weight) using a ball bearing tissue grinder (BioReba AG, Basel, Switzerland). Serial tenfold dilu-

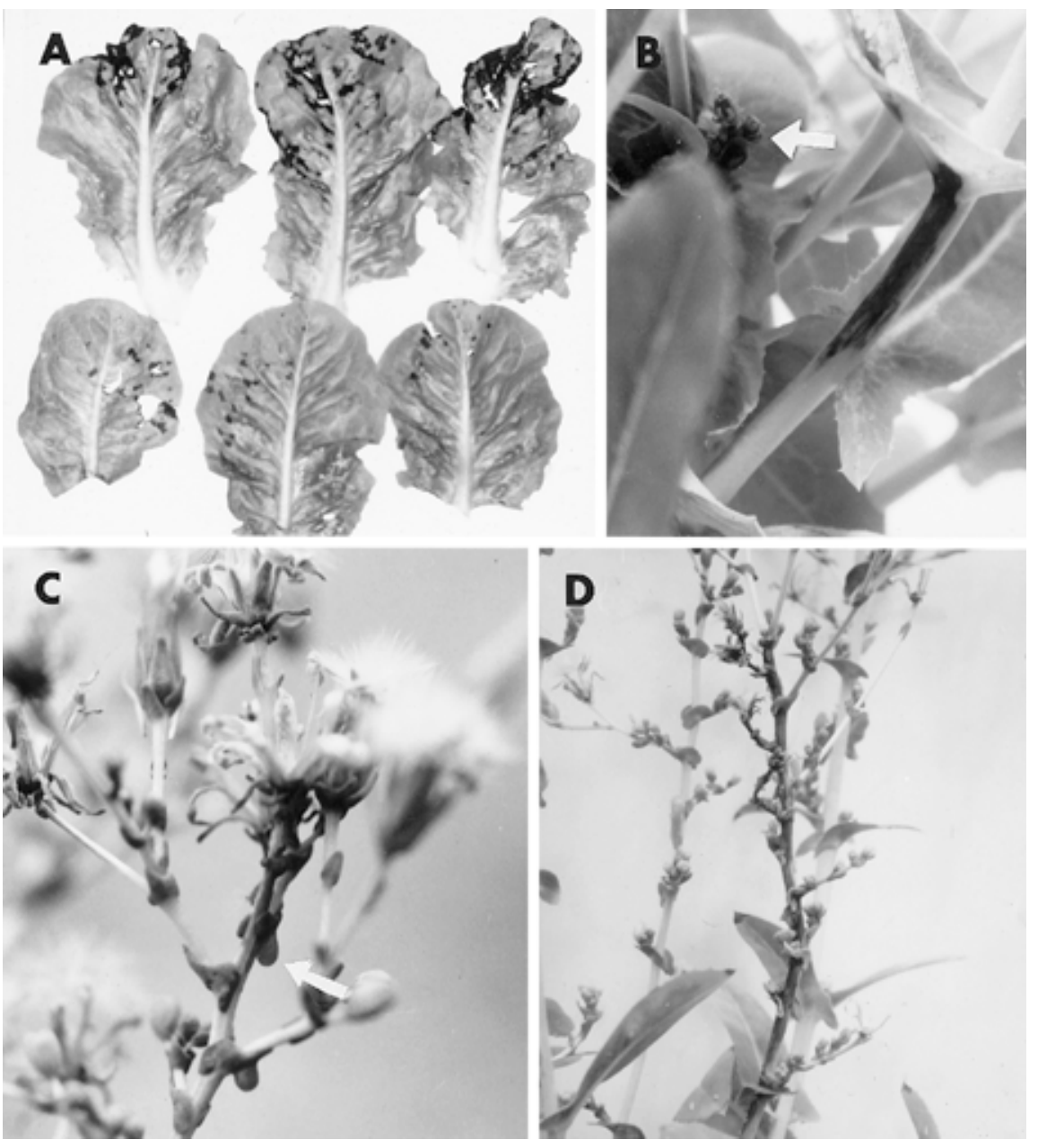

Fig. 1. Typical symptoms of bacterial leaf spot, caused by Xanthomonas campestris pv. vitians on lettuce. (A) Necrotic spots surrounded by chlorotic halos on the green leaf lettuce cultivar Darkland; (B) dark brown stem lesion originating at the node, and necrotic flower buds (arrow); (C) yellowbrown bacterial exudates from stem and flower stalks (arrow); and (D) long necrotic lesions on stem and flower stalks, progressing into flower buds. tions were performed in sterile distilled water, and $0.1 \mathrm{ml}$ of the appropriate dilutions were plated on two plates each of YDC and CKTM. Characteristic X. campestris pv. vitians colonies were counted after the plates were incubated for 4 days at $28^{\circ} \mathrm{C} . \log _{10}$ transformations were used for analysis of all bacterial population data. Analysis of variance (ANOVA) tests were performed to analyze the differences between varieties. Means for each treatment were separated by calculating Fisher's least significant difference at $P \leq 0.05$. Regression analyses were performed to compare disease ratings with bacterial populations and percentage seeds contaminated with $X$. campestris pv. vitians.

Effect of seed treatment. Lettuce plants from the eight cultivars listed above were inoculated with $X$. campestris pv. vitians as described and incubated for 3 months in a greenhouse with ambient light and temperatures of 24 to $28^{\circ} \mathrm{C}$. Seeds from these plants were harvested and tested for contamination with $X$. campestris pv. vitians by directly plating five replications of 20 seeds from each lettuce cultivar on CKTM and YDC. The plates were incubated at room temperature for 2 weeks. Those seeds from which characteristic yellow colonies grew were counted. The identity of representative colonies recovered from contaminated seeds as $X$. campestris pv. vitians was confirmed by fulfilling Koch's postulates on Darkland plants. The experiment was performed three times within 2 weeks after seeds were harvested.

The efficacy of sodium hypochlorite as a treatment to eliminate $X$. campestris pv. vitians from seed was determined by treating 500 seeds collected from diseased plants (cv. Darkland) for $5 \mathrm{~min}$ in $0.52 \%$ $\mathrm{NaClO}$, followed by a brief rinse in sterile distilled water and drying for $30 \mathrm{~min}$ in a sterile hood before plating on CKTM. Seeds from which characteristic yellow colonies grew were counted. Five hundred infested seeds treated with water served as a control. The experiments were performed three times with two replications each. Germination of the treated and control seeds was determined by counting the number of germinated seeds on CKTM after the 8-day incubation period. These experiments were performed approximately 1 year after seeds were harvested. All tests in this study were repeated at least two times.

\section{RESULTS}

Isolation, identification, and characterization of $X$. campestris pv. vitians strains. A yellow mucoid bacterium was consistently isolated from lettuce samples with typical bacterial leaf spot symptoms collected from three commercial muck soil fields in north central Ohio. All five strains isolated from lettuce plants, and X. campestris pv. vitians-type strain LMG 938, were gram negative, rod-shaped, motile, 
aerobic, catalase-positive, and oxidasenegative. All were slightly pectolytic but not amylolytic. All were identified as $X$. campestris pv. vitians by FAME analysis, with similarity indices ranging from 0.416 to 0.728 . All strains were pathogenic on the lettuce cultivar Darkland, causing typical bacterial leaf spot symptoms within 2 weeks after inoculation (Fig. 1A). Symptoms were observed on leaves, stems, and floral bracts above the inoculated leaves, indicating systemic movement of the bacteria upward through the plant (Fig. 1AD). Symptoms on stems appeared as dark brown lesions around the leaf nodes (Fig. 1B). Lesions gradually enlarged longitudinally and turned purple-brown with age (Fig. 1D). Yellow-brown bacterial exudates were commonly observed on the surface of stem lesions and floral bracts, which tended to become blighted later (Fig. 1C and D).

None of the five $X$. campestris pv. vitians strains were resistant to copper sulfate; one strain was resistant to $100 \mu \mathrm{g} / \mathrm{ml}$ streptomycin sulfate.

Evaluation of commercial lettuce cultivars for resistance to $X$. campestris $\mathrm{pv}$. vitians. Four disease susceptibility groupings (highly susceptible, susceptible, partially resistant, and resistant) were devised based on disease severity ratings, leaf bacterial populations, and percentage of $X$. campestris pv. vitians-infested seeds in plants previously inoculated with the pathogen (Table 1). The highly susceptible (HS) cultivars (Darkland, Go Go Green, and Slobolt) had disease severity values (DSVs; 3.3 to 3.9 ) and proportion of infested seeds (16.5 to $18 \%)$ that were significantly $(P \leq 0.05)$ higher than the other cultivars tested. In the susceptible (S) cultivar Tiara, the DSV of 2.7 was significantly lower than the DSV of the highly susceptible cultivars, yet higher than those of all remaining cultivars except Focus. The third category, partially resistant (PR), contained the cultivars Focus, Crisp and Green, and Carmona, with DSVs of 2.1 to 2.4 , significantly lower than the highly susceptible and susceptible cultivars, but higher than the cultivar Redine (DSV = 1.3). Redine was the only cultivar tested considered resistant (R) to $X$. campestris pv. vitians, showing virtually no symptoms, generally lower bacterial populations $\left(1.0 \times 10^{9} \mathrm{CFU} / \mathrm{g}\right)$, and only $1 \%$ infested seeds. Bacterial populations $\left(10^{9}\right.$ to $10^{12}$ $\mathrm{CFU} / \mathrm{g}$ ) for inoculated leaves were high for all cultivars tested, even when few leaf spots were observed (e.g. cv. Redine). Bacteria were also detected on or in newer, non-inoculated leaves of previously inoculated plants of all cultivars, but bacterial populations could only be approximated (Table 1). The regression analyses indicated that there was a strong correlation between disease severity ratings and both bacterial populations and percentage infested seed $\left(R^{2}=0.861\right.$ and 0.949 , respectively; Fig. 2).

Effects of seed treatment. $X$. campestris pv. vitians was recovered from only 1 of 3,000 lettuce seeds treated with $0.52 \%$ $\mathrm{NaClO}$, compared to $10.5 \%$ contamination of untreated seeds. No significant differences $(P \leq 0.05)$ were observed in germination of treated seed (97.3\%) compared to non-treated seed $(96.4 \%)$.

\section{DISCUSSION}

Bacterial leaf spot of lettuce was observed in Ohio for the first time in 1995. The causal agent, $X$. campestris pv. vitians, is a seed-borne pathogen, may be introduced with infested seeds, and may remain problematic for lettuce production in Ohio. Since none of the strains identified in this study were resistant to copper sulfate, resistance may be rare in Ohio at this time, and application of copper-containing fungicides at appropriate times during the growing season could help reduce development of the disease. However, it is likely that intensive use of copper-containing materials will result in an increase in copper resistance in the bacterial population $(6,11)$. The use of streptomycin is not a viable management option in Ohio, since

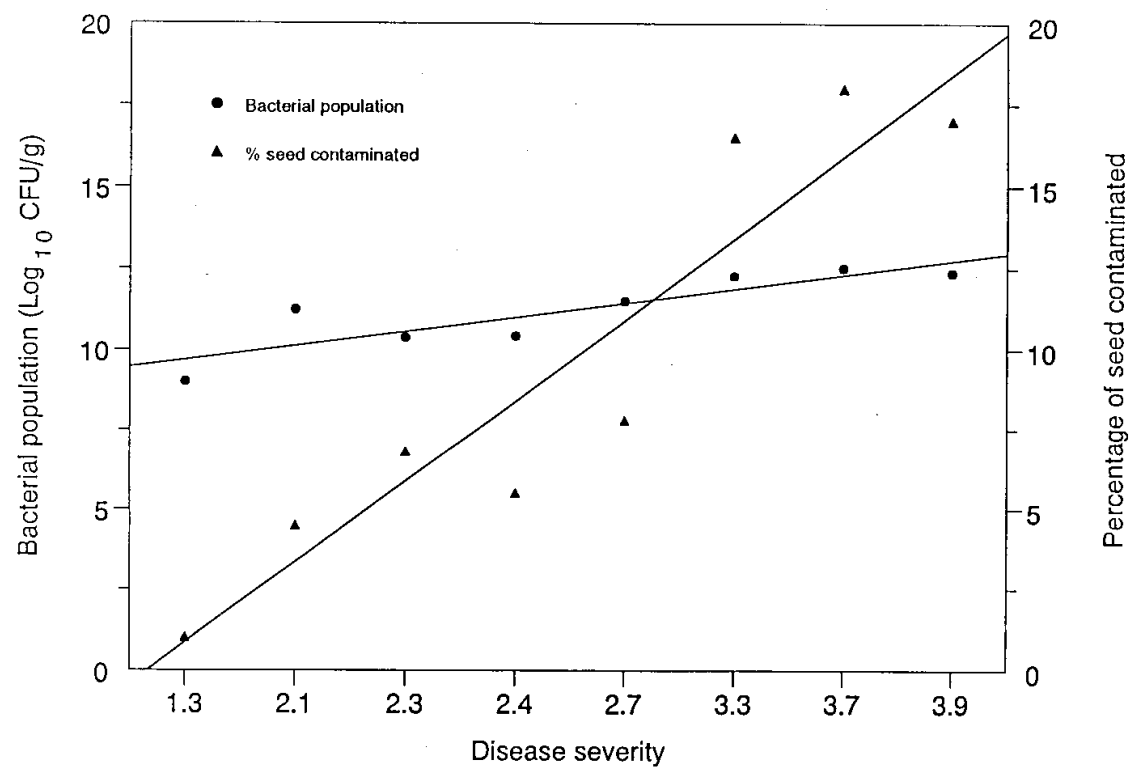

Fig. 2. Relationship of disease severity to bacterial population $\left(\log _{10} \mathrm{CFU} / \mathrm{g}\right)$ and percentage of seed contaminated with Xanthomonas campestris pv. vitians. $R^{2}$ values were 0.861 and 0.949 , respectively. Regression equations: $Y=-4.78+0.669 X\left(\log _{10} \mathrm{CFU}\right) ; Y=1.42+0.131 X(\%$ of seed contaminated).

Table 1. Evaluation of eight lettuce cultivars for disease severity, bacterial population, and percentage of seeds contaminated with Xanthomonas campestris pv. vitians

\begin{tabular}{|c|c|c|c|c|c|c|}
\hline \multirow[b]{2}{*}{ Cultivars } & \multirow[b]{2}{*}{ Lettuce type } & \multirow{2}{*}{$\begin{array}{l}\text { Type of } \\
\text { reaction }^{x}\end{array}$} & \multirow{2}{*}{$\begin{array}{l}\text { Average } \\
\text { DSVy }^{y}\end{array}$} & \multicolumn{2}{|c|}{$\begin{array}{l}\text { X. campestris pv. vitians population } \\
\left(\log _{10} \mathrm{CFU} / \mathrm{g}\right)^{\mathrm{w}}\end{array}$} & \multirow{2}{*}{$\begin{array}{l}\% \text { seeds infested with } \\
\text { X. campestris pv. vitians }\end{array}$} \\
\hline & & & & Inoculated & New leaves & \\
\hline Darkland & Romaine (cos) & $\mathrm{HS}$ & $3.9 \mathrm{a}^{\mathrm{z}}$ & $12.4 \mathrm{a}$ & 6.5 & $17.0 \mathrm{a}$ \\
\hline Go Go Green & Green leaf & HS & $3.7 \mathrm{ab}$ & $12.5 \mathrm{a}$ & 6.5 & $18.0 \mathrm{a}$ \\
\hline Slobolt & Green leaf & HS & $3.3 \mathrm{~b}$ & $12.3 \mathrm{a}$ & $<5.0$ & $16.5 \mathrm{a}$ \\
\hline Tiara & Green leaf & $\mathrm{S}$ & $2.7 \mathrm{c}$ & $11.5 \mathrm{ab}$ & $<5.0$ & $9.8 \mathrm{~b}$ \\
\hline Focus & Butterhead & PR & $2.4 \mathrm{~cd}$ & $10.4 \mathrm{bc}$ & $<5.0$ & $5.5 \mathrm{bcd}$ \\
\hline Crisp and Green & Green leaf & PR & $2.3 \mathrm{~d}$ & $10.4 \mathrm{bc}$ & $<5.0$ & $6.8 \mathrm{bc}$ \\
\hline Carmona & Red leaf & PR & $2.1 \mathrm{~d}$ & $11.2 \mathrm{ab}$ & $<5.0$ & $4.3 \mathrm{~cd}$ \\
\hline Redine & Red leaf & $\mathrm{R}$ & $1.3 \mathrm{e}$ & $9.0 \mathrm{c}$ & $<5.0$ & $1.0 \mathrm{cde}$ \\
\hline
\end{tabular}

\footnotetext{
${ }^{\mathrm{w}} \log _{10}$ numbers of $X$. campestris pv. vitians in CFUs per gram fresh leaf tissues.

${ }^{x} \mathrm{HS}=$ highly susceptible; $\mathrm{S}=$ susceptible; $\mathrm{PR}=$ partially resistant; $\mathrm{R}=$ resistant.

y Average disease severity value from three experiments, each with five replications.

${ }^{\mathrm{z}}$ Values followed by different letters in the same column differ significantly at $P \leq 0.05$.
} 
this antibiotic is not registered for use on lettuce transplants in the greenhouse or in production fields.

Treatment of seeds might be a more promising management option to reduce or eliminate $X$. campestris pv. vitians populations. Treatment with $0.52 \% \mathrm{NaClO}$ reduced $X$. campestris pv. vitians contamination from 10.5 to $0.03 \%$ in this study. It is possible that a slightly longer treatment time or higher concentration of $\mathrm{NaClO}$ would result in complete elimination of $X$. campestris pv. vitians from seeds. However, since it appears that the pathogen moves systemically through the plant, the possibility that bacteria may be internally seedborne cannot be ruled out. More intensive treatments, such as hot water, may be needed to eliminate $X$. campestris pv. vitians internally from lettuce seed.

Evaluation of eight commercial lettuce cultivars typically grown in Ohio showed that only one, Redine, was highly resistant to bacterial leaf spot, while three others, Focus, Carmona, and Crisp and Green, were partially resistant. Four cultivars, Tiara, Darkland, Go Go Green, and Slobolt were susceptible or highly susceptible. Pernezny et al. 1995 (10) also reported severe disease on romaine (e.g. Darkland) and butterhead (e.g. Focus) lettuce types.

Relatively high populations of $X$. campestris pv. vitians were detected on all of the inoculated leaves tested, ranging from $10^{9}$ to $10^{12} \mathrm{CFU} / \mathrm{g}$ fresh weight leaf tissue. Since plants were inoculated with a large number of bacteria $\left(10^{8} \mathrm{CFU} / \mathrm{ml}\right)$, it is likely some of the detected populations are the result of bacteria surviving epiphytically on leaf surfaces. Therefore, the cultivar Redine, which developed few spots after inoculation, would probably not contain high levels of $X$. campestris pv. vitians under field conditions. The fact that the proportion of Redine seed from inoculated plants contaminated with the pathogen was low (1\%) under greenhouse conditions suggests that the concentration of primary inoculum in the cultivar is low.

Effective management strategies for bacterial leaf spot of lettuce should include planting resistant cultivars, where feasible, and seed treatment. The use of coppercontaining fungicides as well as cultural practices including crop rotation, elimination of wild host plants in or around lettuce fields, deep plowing of plant debris, and avoidance of overhead (sprinkler) irrigation would also discourage disease initiation and spread in the lettuce crop.

\section{ACKNOWLEDGMENT}

We thank D. L. Coplin, M. J. Boehm, and M. S. Krause, who provided pre-submission reviews.

\section{LITERATURE CITED}

1. Anonymous. 1996. Vegetables 1996 summary. U. S. Dep. Agric. Nat. Agric. Stat. Serv. Jan. 1997. Vg 1-2 (97). Washington, D.C.

2. Boesewinkel, H. J. 1977. A new disease of lettuce. N. Z. J. Agric. 134:54.

3. Brown, N. A. 1918. Some bacterial diseases of lettuce. J. Agric. Res. 13:367-388.

4. Burkholder, W. H. 1954. Three bacteria pathogenic on head lettuce in New York state. Phytopathology 44:592-596.

5. Dye, D. W. 1962. The inadequacy of the usual determinative tests for the identification of Xanthomonas spp. N. Z. J. Sci. 5: 393-416.

6. Lai, M., Panopoulos, N. J., and Shaffer, S. 1977. Transfer of $\mathrm{R}$ factors among Xanthomonas spp. and other plant pathogenic bacteria. Phytopathology 67:1044-1050.

7. Lelliot, R. A., and Stead, D. E. 1987. Methods for the diagnosis of bacterial diseases of plants. Blackwell Scientific Publications, Ltd., Oxford.

8. Ohata, K., Tsuchiya, Y., and Shirata, A. 1979. Difference in kinds of pathogenic bacteria causing head rot of lettuce of different cropping types. Ann. Phytopathol. Soc. Jpn. 45:333-338.
9. Patterson, C. L., Grogan, R. G., and Campbell, R. N. 1986. Economically important diseases of lettuce. Plant Dis. 70:982-987.

10. Pernezny, K., Raid, R. N., Stall, R. E., Hodge, N. C., and Collins, J. 1995. An outbreak of bacterial spot of lettuce in Florida caused by Xanthomonas campestris pv. vitians. Plant Dis. 79:359-360.

11. Ritchie, D. F., and Dittapongpitch, V. 1991 Copper- and streptomycin-resistant strains and host differentiated races of Xanthomonas campestris pv. vesicatoria in North Carolina. Plant Dis. 75:733-736.

12. Sasser, M. 1990. Identification of bacteria through fatty acid analysis. Pages 199-204 in: Methods in Phytobacteriology. Z. Klement, K Rudolph, and D. Sands, eds. Akademiai Kiado, Budapest.

13. Schaad, N. W., and Stall, R. E. 1988. Xanthomonas. Pages 81-94 in: Laboratory Guide for Identification of Plant Pathogenic Bacteria. 2nd ed. N. W. Schaad, ed. American Phytopathological Society, St. Paul, MN.

14. Schroth, M. N., Thompson, J. P., Bardin, R., and Greathead, A. 1964. Bacterial spot of lettuce. Calif. Agric. 18: 2-3.

15. Sijam, K., Chang, C. J., and Gitaitis, R. D. 1991. An agar medium for the isolation and identification of Xanthomonas campestris pv. vesicatoria from seed. Phytopathology 81:831-834.

16. Steel, F. J. 1961. The oxidase reaction as a taxonomic tool. J. Gen. Microbiol. 25:297301.

17. Stefani, E., Raio, A., Bazzi, C., and Zoina, A. 1994. Identification and grouping of Xanthomonas campestris pv. vitians using SDSPAGE. Phytopathol. Mediterr. 33:99-104.

18. Suslow, I. V., Schroth, M. N., and Isaka, M. 1982. Application of a rapid method for Gram differentiation of plant pathogenic and saprophytic bacteria without staining. Phytopathology 72:917-918.

19. Wallis, F. M., and Joubert, J. J. 1972. Bacterial spot of lettuce in Natal. Landbouwet. S Afr. Agric. Sci. S. Afr. Phytophylactica 4:137138.

20. Yang, P., Vauterin, L., Vancanneyt, M., Swings, J., and Kersters, K. 1993. Application of fatty acid methyl esters for the taxonomic analysis of the genus Xanthomonas. Syst. Appl. Microbiol. 16:47-71. 